\title{
MOSQUITO-LARVICWAL ACTIVITY OF SOME SRI LANKAN PLANTS
}

\author{
S.S. RANAWEERA \\ Department of Botany, University of Sri Jayewardenepura, Nugegoda.
}

\section{(Received: 28 March 1995; accepted:12 January 1996).}

\begin{abstract}
Screening of plants of Sri Lanka for mosquito-larvicidal activity, revealed that 18 plant species out of 53 tested were lethal to Culexquinquefasciatus larvae. Methanol extracts of Camellia sinensis, methanol and petroleum ether extracts of Acorus calamus and petroleum ether extracts of Cymbopogon nardus, Languas galanga, Canarium zeylanicum and Curcuma domestica displayed significant mosquito-larvicidal activity $\left(\mathrm{LC}_{50}<10.0 \mathrm{mg} / \mathrm{l}\right)$ against late $3 \mathrm{rd}$ instar Culex larvae. High mosquito-larvicidal activity was observed in the steam distillate of Acorus calamus (3.6-7.7 mg/) against late 3rd instar mosquito larvae of C. quinquefasciatus, Aedes aegypti, Aedes albopictus, Anopheles tessellatus and Anopheles subpictus. The essential oil of $C$. nardus (Ceylon citronella) too displayed a significant activity $(6.3 \mathrm{mg} / 1)$ against $C$. quinquefasciatus and lesser activity against $A$. aegypti $(9.3 \mathrm{mg} / 1)$. Petroleum ether extract of the rhizome of $L$. galanga was similarly effective against C. quinquefasciatus $(8.3 \mathrm{mg} / \mathrm{l})$ and A. albopictus $(9.3 \mathrm{mg} / \mathrm{l})$. The essential oil of $C$. domestica had high larvicidal activity (4.5 $\mathrm{mg} / \mathrm{l})$ against Anopheles culicifacies which was resistant to other plant extracts. The results suggest that potent mosquito-larvicidal compounds may be isolated from A. calamus, C. nardus and $C$. domestica.
\end{abstract}

Key words: Mosquito-larvicidal activity, essential oils, mosquitoes, plants.

\section{INTRODUCTION}

The long term use of synthetic insecticides has created a number of ecological and medicinal problems such as the development of resistant insect strains, ecological imbalance and high toxicity to mammals. ${ }^{1}$ Plants are known to contain compounds of insecticidal ${ }^{2-4}$, insect-repelling ${ }^{2,5}$ and insect anti-juvenile ${ }^{6}$ properties. Most of these compounds are biodegradable and less harmful to mammals than synthetic insecticides. Therefore, there is a possibility of replacing synthetic insecticides with insecticides of plant origin.

Pyrethrins obtained from Chrysanthemum cinerafolium are still widely used as insecticides and insect-repellents in Africa and South America. ${ }^{4}$ The insecticidal activity and photostability of natural pyrethrin have been increased by chemical synthetic methods. Apart from pyrethrins, the terminal epoxy derivative of geranylgeraniol obtained from Pterodon pubescens has been reported to be highly lethal to the trematode Schistosoma mansoni. ${ }^{3}$ The insecticidal activity of Acorus calamus against many insects has been reported. ${ }^{7}$ Steam volatile principle of the rhizomes of A. calamus $\mathrm{L}$. has been shown to be toxic to adult Culex mosquitoes. ${ }^{8}$ However, there is no recorded information on the availability of compounds of plant origin, which possess mosquito-larvicidal activity. 
It was, therefore, considered important to screen the plants grown in Sri Lanka, for mosquito-larvicidal activity. The present study describes the mosquito-larvicidal activity of some local plant extracts of Sri Lanka against several species of Culex, Aedes and Anopheles.

\section{METHODS AND MATERIALS}

Plant material: Plants for screening for mosquito-larvicidal activity (Table 1) were selected randomly and also on the basis of the information gathered from native people living in rural areas of Sri Lanka. Plant specimens were identified by comparison with reference material at the National Herbarium, Royal Botanic Gardens, Peradeniya, Sri Lanka. Plants were washed in running water and were separated into plant parts (leaves, stem, root, bark etc.) and were . air-dried.

Preparation of plant extracts: For preliminary screening for mosquito-larvicidal activity, air dried plant material ( $10 \mathrm{~g}$ ) were chopped and macerated with $100 \mathrm{ml}$ solvent for extraction (light petroleum ether, methanol or water). The extracts were transferred to conical flasks $(250 \mathrm{ml})$ and were shaken in an orbital shaker for $1 \mathrm{~h}$. After filtration methanol and light petroleum ether were evaporated to dryness under reduced pressure and the residues were redissolved in $5 \%$ aqueous ethanol $(100 \mathrm{ml})$ and later used for the bioassay. The water extracts were directly used for the bioassay.

The plant specimens which showed considerable larvicidal activity (Table 2) were further extracted with each solvent (hexane, light petroleum (40-60\%) and methanol) separately and sequentially (in order: hexane, light petroleum ether and methanol) by refluxing in a Soxhlet apparatus for $24 \mathrm{~h}$. Extracts obtained were evaporated to dryness under reduced pressure and the residues were redissolved in $5 \%$ aqueous ethanol $(100 \mathrm{ml})$ and later used for the bioassay.

Essential oils in samples were extracted by steam distillation of plant samples using a Clevanger distillation apparatus as described previously. ${ }^{9}$

Test organisms: Late 3 rd instar larvae of six mosquito species : Culex quinquefasciatus Say, Aedes aegypti L, Aedes albopictus Skuse, Anopheles culicifacies Giles, Anopheles tessellatus Theobald and Anopheles subpictus Grassi, were used for bioassay. For preliminary screening, C. quinquefasciatus was used as the test species. 
Table 1: Mosquito-larvicidal actiivity of plant extracts against late 3rd instar larvae of Culex quinquefasciatus.

Plant $^{\mathrm{a}} \quad$ Solvent $^{\mathrm{b}}$ Activity $^{\mathrm{c}}$
Part

ARACEAE

Acorus calamus L.

BURSERACEAE

Canarium zeylanicum (Retz.)Bl. POACEAE

Cymbopogon citratus (DC.) Stapf

Cymbopogon confertiflorus Stapf

Cymbopogon nardus (L.) Rendle

Cymbopogon winterianus Jowitt

LAURACEAE

Cinnamomum camphora (L.) T. Nees \& Eberm.

Cinnamomum litseifolium Thw.

Cinnamomum multifolium Wright.

Cinnamomum zeylanicum Bl.

FABACEAE

Derris scandens (Roxb.) Benth.

\section{RUTACEAE}

Atalantia rotundifolia (Thw.) Tan.

RUBIACEAE

Ophiorrhiza mungos L.

THEACEAE

Camellia sinensis (L.) Kuntz

ZINGIBERACEAE

Curcuma domestica Valet.

Curcuma zedoria (Berg) Roscoe

Languas galanga (L.) Stuntz

$\mathrm{Rh}$;Lf $\mathrm{MeOH}$;Pet $\quad++++$

Sd;Lf $\mathrm{MeOH}$;Pet $\quad+++$

Elettara repens (Sonner.) Baill

Zingiber zerumbet (L.) Sm.

$\begin{array}{lll}\text { Lf } & \text { Pet } & ++ \\ \text { Lf } & \text { Pet } & ++ \\ \text { Lf } & \text { Pet } & +++ \\ \text { Lf } & \text { Pet } & ++\end{array}$

Lf Pet

Lf Pet +

Lf Pet +

Lf Pet +

+
+

Rt $\mathrm{MeOH}++$

Lf Pet + +

Lf $\mathrm{MeOH}++$

$\mathrm{Sd} \quad \mathrm{MeOH} \quad+++$

Lf = leaf, $\mathrm{Rh}=$ Rhizome, Rt $=$ Root, $\mathrm{Sd}=$ Seed

b Pet $=$ Light petroleum ether, $\mathrm{MeOH}=$ Methanol

c Larvicidal Activity, $\left(\mathrm{LC}_{50}\right.$ value, $\left.\mathrm{mg} / \mathrm{l}\right)$

$$
\begin{aligned}
& ++++\quad=5.0 ; \quad+++=5.1-10.0 \\
& ++\quad=10.1-15.0 ;+\quad=15.1-20.0
\end{aligned}
$$


Table 2:. $\mathrm{LC}_{50}$ values $(\mathrm{mg} / \mathrm{l})$ of different plant extracts for late 3rd instar larvae of Culex, Aedes and Anopheles species.

\begin{tabular}{|c|c|c|c|c|c|c|c|}
\hline \multirow[t]{2}{*}{ Plant } & \multirow[t]{2}{*}{ Extract } & \multicolumn{6}{|c|}{ Mosquito species ${ }^{\mathrm{b}} / \mathrm{LC}_{50}, \mathrm{mg} / \mathrm{l}$} \\
\hline & & C.q. & A.e. & A.a. & A.c. & A.t. & A.s. \\
\hline \multirow[t]{4}{*}{ Acorus calamus } & E.o & 3.60 & 6.20 & 7.72 & 12.00 & 5.25 & 6.50 \\
\hline & Hex & 4.00 & 7.93 & 9.31 & 13.63 & 8.30 & - \\
\hline & Pet & 4.60 & 8.27 & 10.60 & 18.50 & 9.22 & - \\
\hline & $\mathrm{MeOH}$ & 4.70 & 8.81 & 10.90 & 19.77 & 11.87 & - \\
\hline Canarium zeylanicum & Pet & 9.60 & 10.40 & 11.10 & - & - & - \\
\hline Cymbopogon narảus & E.o & 6.30 & 9.32 & 34.00 & 14.25 & 15.41 & - \\
\hline Camellia sinensis & $\mathrm{MeOH}$ & 8.00 & 9.30 & 10.20 & - & - & - \\
\hline \multirow[t]{2}{*}{ Curcuma domestica } & E.o & 9.20 & 12.50 & 11.20 & 4.50 & 12.67 & - \\
\hline & Pet & 9.70 & - & - & - & - & - \\
\hline Languas galanga & Pet & 8.25 & 10.86 & 9.30 & 12.22 & 13.85 & - \\
\hline
\end{tabular}

"Pet $=$ Light petroleum ether, $\mathrm{MeOH}=$ Methanol, $\mathrm{Hex}=$ Hexane, E.o $=$ Essential oil

b. C.q.= Culex quinquefasciatus; A.e.= Aedes aegypti; A.a.= Aedes albopictus; A.c.= Anopheles culicifacies; A.t. $=$ Anopheles tessellatus; A.s. $=$ Anopheles subpictus

- Not tested

Mosquito bioassay: $\mathrm{LC}_{50}$ values of plant extracts for mosquito larvae were determined by the procedure followed by The World Health Organization ${ }^{10}$ with slight modifications. For bioassay, healthy late 3rd instar mosquito larvae were distributed in batches of 20 in beakers containing $25 \mathrm{ml}$ water. Test dispersions $(25 \mathrm{ml})$ were prepared in separate beakers by adding different amounts of the extract so that a series of ten final concentrations ranging from 20 to $200 \mathrm{ppm}$ was produced, when the contents with larvae in beakers were added to the latter (final volume, $50 \mathrm{ml}$ ). Mortality counts were taken after $24 \mathrm{~h}$ and the bioassay was carried out at $29^{\circ} \mathrm{C}$. Each bioassay was carried out with five replicates. $\mathrm{LC}_{50}$ values were estimated from a probit/log concentration graph.

\section{RESULTS AND DISCUSSION}

\section{Preliminary screening of plant extracts}

The results of screening plants for mosquito-larvicidal activity (Table 1) indicate that 18 plant species out of 53 tested were lethal to Culex quinquefasciatus larvae. The extracts of Acorus calamus, Cymbopogon nardus, Languas galanga, Camellia sinensis, Canarium zeylanicum and Curcuma domestica displayed significant larvicidal activity $\left(\mathrm{LC}_{50}<10.0 \mathrm{mg} / \mathrm{l}\right)$ against late $3 \mathrm{rd}$ instar larvae of C. quinquefasciatus. 
Among the species tested the following plant species had very low $\left(\mathrm{LC}_{50}>20.0\right.$ $\mathrm{mg} / \mathrm{l})$ or no activity : AMARYLLIDACEAE: Pancratium zeylanicum L., Allium cepa L., Allium rubrum L., Allium sativum L.; APOCYNACEAE: Alstonia scholaris (L.) R.Br., Alstonia macrophylla Wall. ex G. Don ; ARACEAE: Alocasia macorrhiza (L.) Schott, Alocasia cucullata (Lour.) Schott, Lasia spinosa (L.) Thw., Amorphophallus campanulatus (Roxb.) Bl.ex. Decne.; ASTERACEAE: Anacyclus pyrethrum, Eupatorium ayapana; EUPHORBIACEAE: Balispormium montanum, Acalypha indica L., Antidesma alexiteria L.; FABACEAE: Atlosia rugosa Wight and Arn., Atylosia trinervia (Spreng.) Gamble, Canavalia ensiformis (L.) DC; MONOMIACEAE: Hortonia floribunda Wight ex Arn.; PIPERACEAE: Piper betle L., Piper longum L., Piper nigrum L.; RUTACEAE: Atalantia monophylla DC., Atalantia ceylanica (Arn.) Oliv., Citrus aurantium L., Citrus grandis (L.) Osb., Citrus hystrix DC. ; RUBIACEAE: Ixora coccinea L., SOLÅNACEAE: Datura suaveolens Humb. \& Bonpl.ex Willd., Solanum jacquini Thw., Solanum indicum L., Solanum nigrum L., Solanum trilobatum L., Capsicum frutescens L. ; SPOTACEAE: Maduca longifolia (L.) J.F.Machr.

\section{Mosquito-larvicidal activity of essential oils and solvent extracts}

Results presented in Table 2 indicate that essential oils of A.calamus, prepared by steam distillation had the highest mosquito-larvicidal activity (3.6-12.0 mg/), against all mosquito species tested except A. culicifacies. C. quinquefasciatus was the most sensitive mosquito species for $A$. calamus oil (3.6 mg/l). The hexane extract of A. calamus was as effective $(4.0 \mathrm{mg} / \mathrm{l})$ as the steam distillate. Light petroleum ether and methanol extracts of A.calamus rhizome were less effective. When the A. calamus rhizome was sequentially extracted with hot hexane, light petroleum ether and methanol, mosquitolarvicidal activity was retained only in the hexane extract (Results are not presented). It has been reported that the toxicity of petroleum ether extracts of A. calamus against adult mosquitoes (C. quinquefasciatus) were almost two fold when compared to that of kerosene. ${ }^{5}$

The essential oil of C. nardus (Ceylon citronella) also displayed a significant activity $(6.3 \mathrm{mg} / \mathrm{l})$ against C.quinquefasciatus and lesser activity against A.aegypti. Citronella oil is well known to be a mosquito-repellant but its mosquito-larvicidal activity has not been tested before.

The petroleum ether extract obtained from the rhizome of $L$. galanga was effective against $C$. quinquefasciatus $(8.3 \mathrm{mg} / \mathrm{l})$ and $A$. albopictus $(9.3 \mathrm{mg} / \mathrm{l})$.

The essential oil of C. domestica had high larvicidal activity $(4.5 \mathrm{mg} / \mathrm{l})$ against A. culicifacies which was resistant to other plant extracts. However, it had very low activity against other mosquito species tested. 
Our results suggest that the essential oils of A.calamus, C. nardus, L.galanga and C.domestica could be used as potent mosquito-larvicides. In order to use these essential oils as mosquito-larvicides it will be necessary to carry out further studies to determine their feasibilty of large scale use, stability of their active compounds under field conditions, and chemical identity of active compounds. The essential oils are complex mixtures of terpenes and there could be more than one compound responsible for the mosquito-larvicidal activity. Therefore, bioassay directed isolation of active components of essential oils of A. calumus, C. nardus, L. galanga and C.domestica should be undertaken.

\section{Acknowledgement}

I thank the University of Sri Jayewardenepura (USJ) for financial support, late Professor W.E. Ratnayake, Department of Zoology, USJ for the mosquito larvae and Mr. W.P.Thilakaratne, Department of Botany, USJ for technical assistance.

\section{References}

1. Marini-Bettolo G.B. (1976). Modern trends in the use of natural products for controlling pests and plantdiseases. In: Proceedings of symposium on natural products and the protection of plants, Vatican, 18-23 October 1976, pp.5-14. Pontificiae Academiae Scientiarum Scripta Varia, Vatican.

2. Abeywickrama B.A. (1975). List of vascular plants of economic importance as food, drugs etc. In: Proceedings of Workshop on Natural Products, Colombo, Sri Lanka, June 1975, pp. 11-31. National Academy of Sciences, U.S.A. \& National Science Council of Sri Lanka.

3. Bandara B.M.R., Gunatilake A.A.L., Sotheeswaran S., Wijeratne E.M.K. \& Ranasinghe M.A.S.K. (1989). Insecticidal properties and active constituents of Limonia acidissima. Journal of the National Science Council of SriLanka 17(2): 237-239.

4. Saxena B.P.\& Srivastava J.B. (1972). Studies on plant extracts with juvenile hormone activity. Effects of Iris ensata Thamb. on Dysdercus koenigii. Indian Journal of Experimental Biology 10(5): 391-393.

5. Krisnarajah S.R., Ganesalingam V.K. \& Senanayake U.M. (1985). Repellency and toxicity of some plant oils and their terpene components to Sitotroga cerealella (Oliver). Tropical Science 25: 249-252. 
6. Bowers W.S., Ohta T., Cleere J. \& Marshella P. (1976). Discovery of antijuvenile hormones in plants. Science 193: 542.

7. Bhaskar P.S. \& Srivastava J.B. (1972). Effect of Acorus calamus L. oil .vapours on Dysdercus koerigii F. Indian Journal of Experimental Biology 10(5): 391-393.

8. Dixit R.S., Perti S.L. \& Ranganathan S.K. (1956). Evaluation of Acorus calamus Linn. Journal of Scientific \& Industrial Research 15(5): 16-22.

9. Brain K.R. \& Turner T.D. (1975). Determination of essential oil content. In: The practical evaluation of phytopharmaceuticals, pp. 86-87. WrightScientechnica, Bristol.

10. Busvine J.R. (1971). Test methods with mosquito larvae. In: A critical review of the techniques for testing insecticides, 2nd ed. pp. 182-183. Commonwealth Agxicultural Bureaux, London. 